\title{
Money, Interest Rates, Prices, And Output
}

T

2HE MONEY SUPPLY and commercial bank credit have risen rapidly since January. In recent months interest rates have also risen markedly. These developments might appear to be a paradox, but a close examination of economic relationships indicates that they can be interpreted in a way which is entirely consistent with economic theory. The developments in financial markets in the past two years have given rise to considerable question concerning the underlying forces affecting interest rates. This note traces these events and relates them to one frequently cited theory. Before discussing interest rate movements during the past two years, the current economic situation is briefly presented.

\section{Recent Developments}

The money stock, defined as private demand deposits plus currency, rose at an estimated 8 per cent annual rate from January to October, while money defined to include time deposits at commercial banks grew at a 12 per cent rate. Looking at the components

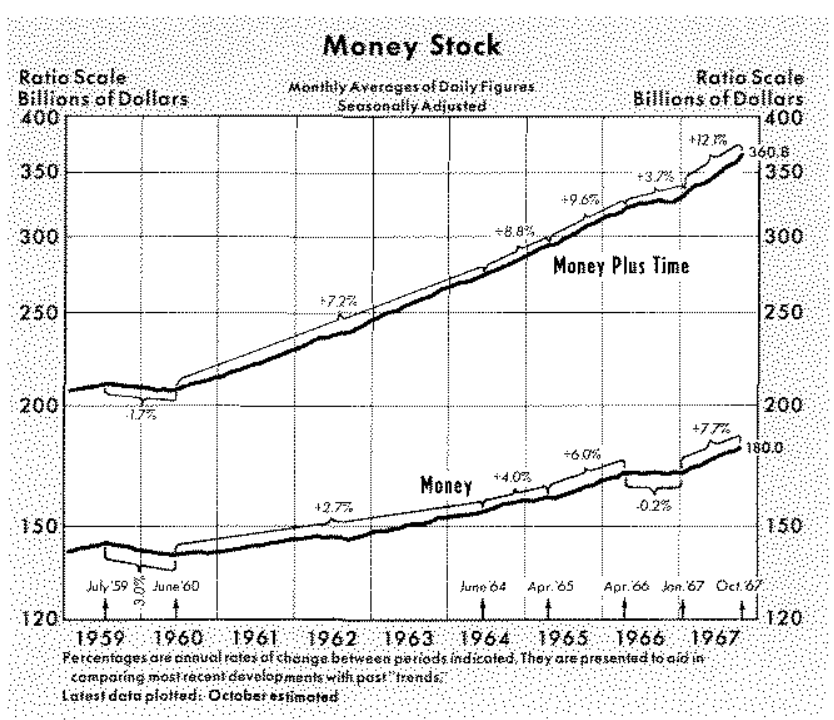

separately, private demand deposits (checking accounts) increased at a 9 per cent rate, currency held by the public at a 5 per cent rate and time deposits at a 17 per cent rate. In each case these rates were much faster than the trend rates.

Underlying the growth of money, total reserves of member banks increased at a 10 per cent annual rate, and reserves available for private demand deposits (total reserves minus required reserves on time, interbank, and Government deposits) increased at a 7 per cent rate. This increase in total reserves compares with a 5 per cent average rate of increase from 1964 to 1966 and a 3 per cent trend rate from 1957 to 1964 . Federal Reserve credit, the main source of new reserves, rose

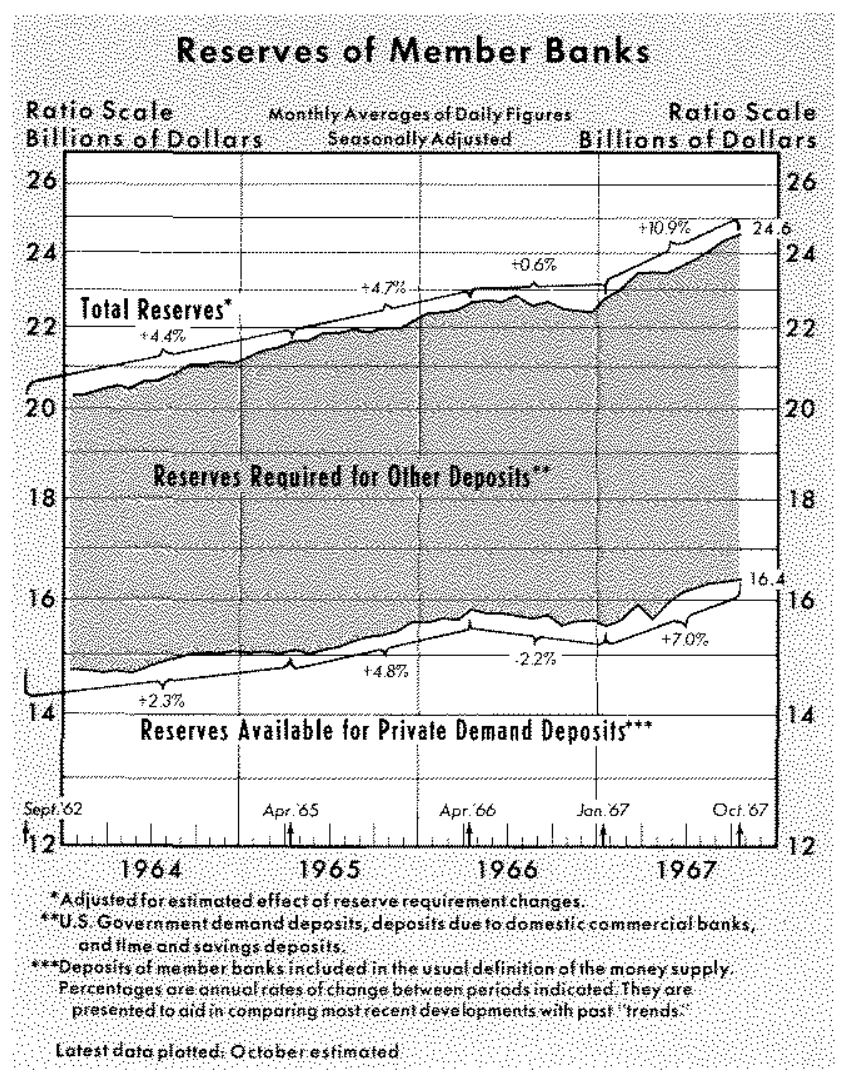


at a 12 per cent rate during the January to October period. The major component of Federal Reserve credit is the System's holdings of U. S. Government securities.

Most business indicators which in the earlier months of this year had indicated some softness turned up during the second quarter and have since risen rapidly. Retail sales increased at a 9.5 per cent annual rate from late spring to early fall, after about a 6 per cent increase during the previous twelve months. The growth trend in these sales from 1957 to 1966 was 5 per cent per year. Despite a major automobile strike, industrial production has risen at a 2 per cent rate since June, after declining at a 3.2 per cent rate from October last year to June. Total employment has risen at about a 3 per cent rate since late spring, somewhat faster than the 2 per cent rate of growth from early fall to late spring.

Gross National Product in current dollars increased at a sharp 8 per cent annual rate from the second to the third quarter this year, after growing at only a 3.4 per cent rate from the fourth quarter of 1966 . Real output rose at a 4.2 per cent rate from the second to the third quarter after growing at only a modest 1 per cent rate from the fourth quarter 1966 to second quarter this year.

As indicated by the widening gap between the GNP figures in current and constant dollars on the chart, overall prices rose at a 3.5 per cent annual rate from the second to third quarter, up from a 2.3 per cent rate in the previous two quarters. Both consumer prices and industrial wholesale prices have been rising again since the May-June period, following a period of little pressure on prices in the previous few months.

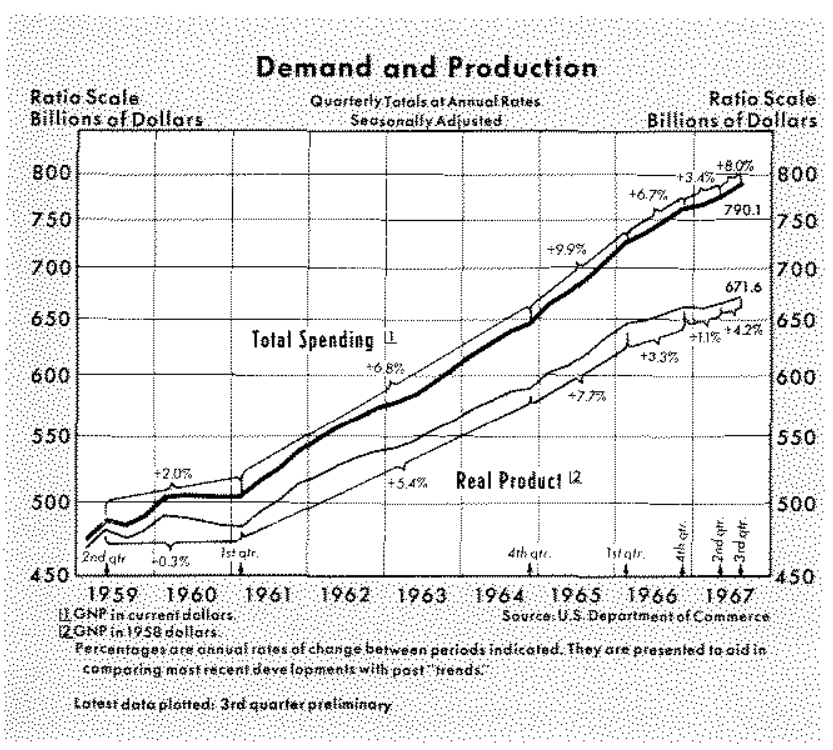

Yields on Selected Government Securities

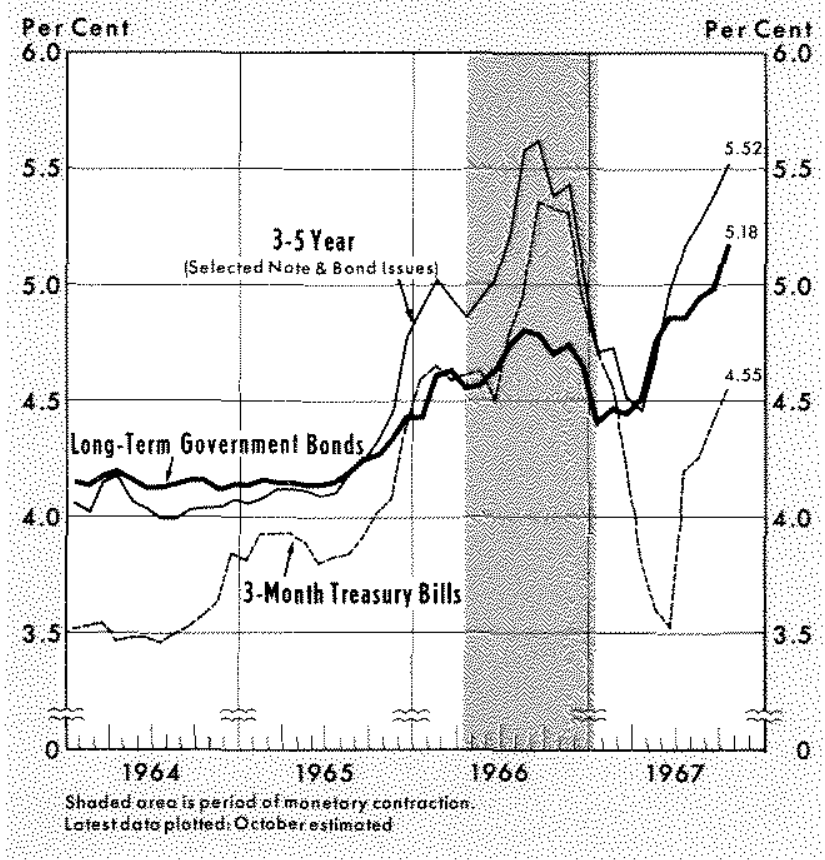

Long-term interest rates on both corporate and Government securities have been rising since early spring and are now well above the highs of a year ago. Yields on short-term securities have risen since mid-year, but are still below 1966 peaks. Since mid June, yields on intermediate-term securities have been higher than on either short or long-term obligations. This same relationship existed during the period of rising rates in the spring and summer of 1966. The implication of this condition may be that the market has been expecting rates on new issues of short-term secur. ities to rise in the near-term, but subsequently to return to a lower level. ${ }^{1}$

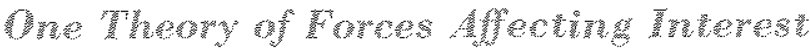

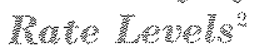

In financial markets, interest rates are the prices at which the quantity supplied and the quantity demanded of particular financial assets are equated. The way in which the money stock is related to the demand for any supply of some financial assets is somewhat complex. On the one hand, an increase in the money supply and bank credit adds directly to the supply of

\footnotetext{
1 For a discussion of the term-structure of interest rates see "Changing Structure of Interest Rates" in the June 1967 issue of this Review.

2 For an attempt to estinate empirically the forces affecting interest rates see W. E. Gibson and G.G. Kaufman, "The Relative Impact of Money and Income on Interest Rates: An Empirical Investigation, Staff Economic Study Number 26; Board of Governors of the Federal Reserve System.
} 


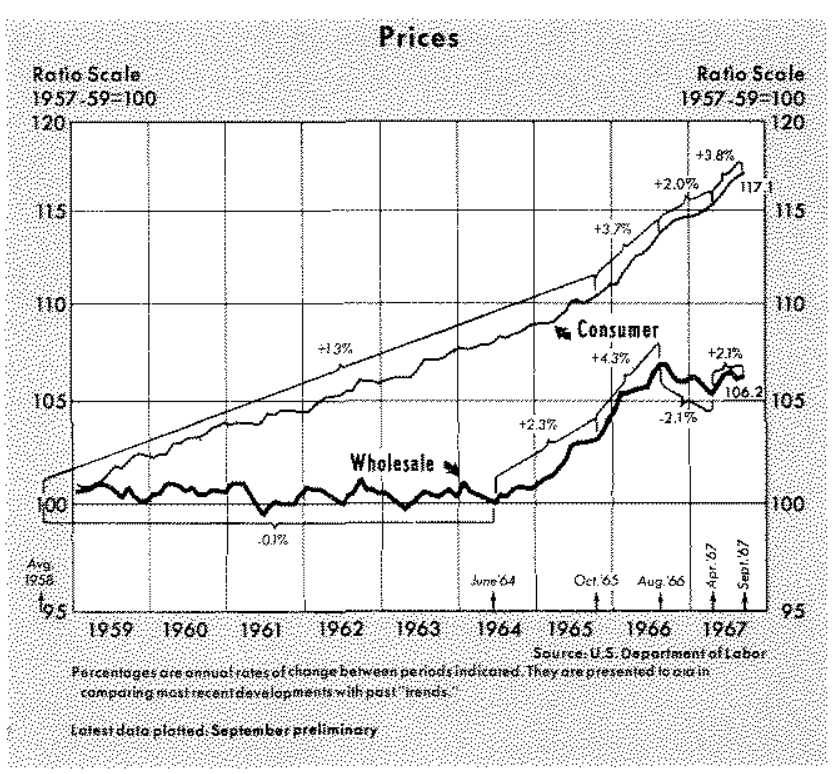

lendable funds. An increase in money results in the bidding up of the prices of financial assets, causing interest rates to be lower than they otherwise would be.

On the other hand, some argue that a rise in the money supply and bank credit also has expansionary effects on the total demand for goods and services. If dollar balances and credit are increased rapidly, given existing assets, incomes, prices, and interest rates, people will attempt to exchange the "excess money" for goods, services, or other financial assets. Any increase in demand for goods and services will result initially in the running down of inventories and, subsequently, a rise in production and an increase in credit demands. If the increased demands for credit which result from a large monetary expansion are greater than the supply of credit created, net upward pressure on interest rates will result after some lag.

If the rates of increase in money supply, credit, and total demand are faster than the rates at which output can be increased, prices will rise. Rising prices also cause increased demands for credit, since more funds are needed to finance a given volume of goods. With expectations of inflation, borrowers are willing to pay higher rates since they expect to repay with cheaper dollars, and lenders charge higher rates in order to net the same real return in the process of allocating limited funds.

According to this view, marked and sustained changes in monetary growth have opposite short and long-run effects on interest rates. Rapid increases of the money supply will cause interest rates to be lower over an immediate short period than they otherwise would be. However, the effects of sustained changes in rates of monetary growth over several months or longer work indirectly in the opposite direction. Prolonged increases in the money supply, at rates greater than the growth in the demand for money to hold, cause increases in the demand for goods, services, credit, and ultimately in prices. As a result, market rates of interest will be adjusted upward as a response to more vigorous credit demands and to compensate for the rise in prices and consequent decrease in the purchasing power of money.

In summary, this theory suggests that the shorter and longer-run effects may, at times, work against each other. At other times, as may have been observed during different periods of the past year and a half, these forces can both be pushing interest rates in the same direction.

\section{Interest Pate Wowements In the Last Tho Years}

The strength of monetary forces and the responsiveness of spending, prices, and interest rates to these forces has been given a rigorous test over the past two years. The rapid monetary growth of 1965 and early 1966 was suddenly halted in the spring of 1966 only to be fully resumed since the beginning of the current year. Compared with a 3.2 per cent trend rate of growth from 1961 to 1965 , money rose 6 per cent from the spring of 1965 to the spring of 1966, remained about unchanged the remainder of that year, and subsequently has risen at an 8 per cent rate. Interest rates, output, and prices responded to both of these sharp reversals of monetary growth in a manner consistent with the theory outlined above.

The advanced rate of monetary growth during 1964 and early 1965 contributed to increases in output and employment, but increases in total demands for goods, services, and credit did not proceed at rates greater than the growth in production. Consequently, prices and interest rates remained relatively stable. Toward the end of 1965 and in early 1966 , the expansion in economic activity fostered an increase in the demands for credit, producing increasing upward pressure on interest rates. This force on rates was moderated to some extent in the short-term by rapid increases in the money supply and bank credit. However, it is argued that the rapid growth in money caused still further stimulation of spending and credit demands, resulting finally in additional upward pressure on interest rates.

When the growth in the money supply was halted in the spring of 1966, this argument continues, the short-run impact was reversed, reinforcing the upward 
pressure on interest rates. At the same time, the longerrun impact of previous money injections continued to be upward for several months. The rapid monetary growth of 1965 and early 1966 provided an expansionary force on spending and output, creating upward pressure on prices into the fall of the year. Thus, interest rates were influenced by both the continuing impact of the previous period of rapid monetary expansion and the immediate effect of the reduced rate of growth in money. Sharply rising interest rates throughout the summer and into the early fall of 1966 were the result.

By the fall of 1966, when the public protests against rising prices and interest rates were loudest, a major source of the inflationary pressure (rapid monetary expansion) had long since disappeared, and economic forces were well advanced in the reversal process. Some economic analysts were already pointing out that the lack of monetary growth since spring would have delayed contractionary effects which would soon be felt. ${ }^{3}$ The thrust of economic expansion began to weaken in late 1966 despite the most stimulative Federal budget in twenty years. With demand for goods slowing, credit demands eased, causing a definite downward trend in interest rates in late 1966 and early 1967.

Shortly after the turn of the year came the second sharp reversal in monetary growth in less than a year. For the first few months, as in the previous summer, short and long-run effects worked in the same direction. The rapid growth in the money stock and available credit produced downward pressure on interest rates, supplementing the trend caused by easing credit demands and reduced pressure on prices.

Following the rapid growth of money early in the year, economic activity gained momentum in the late spring. At this time, most interest rates reached lows for the cycle discussed and began rising. Since then the short-run effect of monetary growth on interest rates has still been downward as the money supply and bank credit continue to grow at rapid rates. However, the upward longer-run effects, via stimulation of spending and credit demands, have again been dominant, as they had been in late 1965 and early 1966 . On balance, this is causing upward pressure on interest rates once again.

Expectations of renewed price inflation have in-

3"Monthly Economic Letter", First National City Bank of New York, September, 1966. And, Karl Brunner, "U.S. Economy in Cross-Cuments Between Monetary and Fiscal Policy: A Reconsideration of the New Economics", Bulletin of Business Research, (Ohio State University, February, 1967). (Publication of a previously delivered speech) creased as upward price trends accelerated during the summer. Adherents to this theory might conclude that the rapid monetary growth through October of this year may have been sufficient to place strong upward pressure on prices and interest rates for some time into the future. So long as the rate of monetary expansion continues to be relatively high, the theory indicates that there will continue to be strong forces leading to higher prices and interest rates. However, if the rate of monetary growth is sharply curtailed with the intention of eventually stopping inflation and achieving lower rates, the short-run effects of the reduced volume of funds would result in even higher interests rates over the near future. This analysis indicates that the economy, as in the spring of 1966, must be willing to bear the temporary cost of higher interest rates in the near term if goals of sustainable growth in total demand, relative price stability, and a lower level of interest rates are subsequently to be achieved.

\section{"The Diferential matipt" of Stabilisurion Polloy}

An interest rate is a price, and as is true of all prices, interest rates serve a rationing function. ${ }^{4}$ Interest rates are the price that allocates available funds between businesses and households. At the same time, they serve to divide the funds among different businesses and among different households, Expected profitability of alternative uses of funds is one of the factors affecting businesses' decisions concerning the amount of funds they demand at various levels of interest rates. Similarly, households' decisions concerning credit purchases and saving are affected by their income constraint and willingness to delay some consumption desires.

In a period of economic expansion, it is reasonable to expect that anticipated profits from investment opportunities in plant and equipment, inventories, land, and housing will improve, but each by different amounts, and that financial assets such as bonds will be sold in order to take advantage of these favorable opportunities. With a given supply of funds, the price of bonds will fall (yields will rise) to the point where the marginal investor is indifferent between the return on bonds and the anticipated return from other investment opportunities.

\footnotetext{
4 We usually talk about interest rates with reference to marketable securities, but it is important to remember that the interest rate applies to all goods. The rate of interest reflects the price or cost of the convenience of earlier availability, natural preference for more certan rather than less certain consumption rights, and the economy's ablity to use resources to increase total output.
} 
In the process, some business and household units are "priced out of the market". This could be called a "differential impact", a term which applies equally well to any pricing or allocation mechanism. Any change in price or method of allocation may be undesirable to some individuals or sectors of the economy. A tax increase, on personal or corporate incomes, on sales or on property, also will be painful to those who must pay more. Less disposable income constrains the volume of purchase, but prices will change in response.

If there are not monetary actions constraining the volume of available funds, or fiscal actions constraining disposable incomes or government expenditures, then prices and interest rates will rise as the market mechanism allocates scarce resources. Inflation causes reallocation of both wealth and command over real output. This is harmful to certain groups of the economy. Finally, allocation by any non-market means, such as price controls and rationing, is undesirable to some.

In a free market economy, interest rates act to al- locate money balances-which represent command over real output-among individuals, firms, and the government sector. A rising interest rate, and possibly a decreasing supply of funds at each level of interest rates, at a time that restraint is initiated, forces certain individuals and firms to reduce their command over real output. This is very disturbing to those adversely effected. However, these temporary ill effects should be weighed against the real benefits for the whole economy from reducing inflationary pressures in the longerrun. In addition, as this theory suggests, the adverse allocation of funds from certain groups will only be temporary since rates are expected to decrease once inflation is controlled. ${ }^{5}$

\footnotetext{
5For other recent discussions of the present financial situation which employ similar theoretical analysis, see A. James Meigs, "A Monetary View," prepared for a session of the National Association of Business Economists, Detroit, Michigan, September 29, 1967. Also, Ralph F. Leach, "Marking Treasury Issues With Conversion", The Weekly Bond Buyer, October 23, 1967, pp. 9-11, and Roy L. Rierson, "Fed's Dilemma. ..", The Weekly Bond Buyer, October 23, 1967, pp. 12-14. Also' see "Trends and Recent Relationships in Yields on U.S. Government Securities", in the October 1967 issue of Economic Review, Federal Reserve Bank of Cleveland.
}

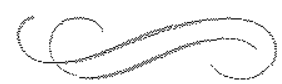

